\title{
A FAILURE “WITHOUT PARALLEL": THE SCHOOL MEDICAL SERVICE AND THE LONDON COUNTY COUNCIL 1907-12
}

by

\section{J. D. HIRST*}

IN HIS Annual Report for 1909 the Chief Medical Officer to the Board of Education, George Newman, was moved to describe the performance by the London County Council (LCC) of its statutory duty under the Education (Administrative Provisions) Act of 1907 to provide for the medical inspection of children attending schools in its area as constituting a failure "without parallel". ${ }^{1}$ Although the dispute between the Board and the LCC which prompted this accusation has been discussed in some detail by Bentley B. Gilbert, ${ }^{2}$ the nature and extent of the Council's failure to implement a measure which had passed through Parliament with relatively little opposition, and which had been welcomed by front-bench spokesmen on both sides of the House, ${ }^{3}$ has not so far been comprehensively and accurately documented. This article attempts to explore the diverse influences which led the LCC, by far the largest education authority in the country, to ignore the instructions of the Board for almost five years, and to discuss the wider implications of the dispute in relation to the development of the School Medical Service nationally.

Paradoxically, the LCC's difficulties stemmed in part from the action of its predecessor, the London School Board (LSB), in appointing, in 1890, the first full-time medical officer to be employed by a British education authority, an action identified by Newman as a landmark in the history of school hygiene in Britain. ${ }^{4}$ In practice, the LSB's action was not as significant a step as it might at first appear. By the 1890s many school boards were obtaining medical advice for a variety of administrative purposes, such as the examination of candidates for teaching appointments, or inspection of children allegedly unfit to attend school. The sheer size of the LSB meant that such examinations, which in most boards would be infrequent or negligible in number,

*J. D. Hirst, B.Sc., M.A., Lecturer in Social Administration, Department of Social Theory and Institutions, University College of North Wales, Bangor LL57 2DG.

\footnotetext{
${ }^{1}$ Board of Education, Annual Report of the Chief Medical Officer for 1909, Cd. 5426, p. 6, BPP 1910, xxiii.

${ }^{2}$ Bentley B. Gilbert, The evolution of National Insurance in Great Britain, London, Michael Joseph, 1966, pp. 131-143.

${ }^{3}$ See Hansard, 4th series, 179: $1097 \mathrm{ff}$. The Unionist leadership, although concerned about the financial implications of medical inspection, had previously agreed not to oppose its introduction. Public Record Office (PRO), Ed 24/128, letters from Sir William Anson and Sir Robert Morant.

4 Board of Education, Annual Report of the Chief Medical Officer for 1908, Cd. 4986, p. 4. BPP 1910, xxiii.
} 


\section{J. D. Hirst}

represented a constant demand on the services of the medical adviser. By 1903, 2,738 medical examinations of candidates for appointments under the Board were made, ${ }^{5}$ and the Board's original intention was to use the medical officer only for examination of candidates, and to give general medical advice. ${ }^{6}$ The appointment of Dr. James Kerr as full-time medical officer by the much smaller Bradford School Board in 1893 was thus a significantly more radical use of the 1870 Elementary Education Act's power to appoint "necessary officers".' Furthermore, unlike Kerr, the LSB's original medical officer, Professor W. R. Smith, was a full-time appointee in name only, and continued to hold a number of other public and private appointments in conjunction with his post at the LSB. ${ }^{8}$ In 1901, after members of the Board voted to refuse him a salary increase unless he relinquished his other appointments, Smith resigned, and was succeeded as medical officer by James Kerr. ${ }^{9}$

Despite the criticisms of the Board members, there had been some developments in the medical activities of the Board during Smith's term of office, including the introduction of vision testing in schools, and the expansion of provisions for handicapped children. These had resulted in the appointment of a number of part-time assistants for Smith. With the appointment of Kerr, however, the expansion of the medical department's work proceeded more quickly. At Bradford, his appointment had given him the time and opportunity to develop a range of activities aimed at improving the hygiene of schools, and the health of pupils and teachers. ${ }^{10} \mathrm{He}$ extended the existing boundaries of school hygiene, particularly through his work on dyslexia. ${ }^{11}$

Once in London, Kerr began a systematic expansion of the activities and staff of the medical department, on the lines of his work at Bradford. School nurses were appointed to inspect children for the presence of ringworm and pediculosis, while the existing vision testing programme was developed into a more general system of "routine" medical supervision, at first confined to Board schools, later, when the LCC took over the functions of the LSB, extended to voluntary schools also. Access to the voluntary schools flushed out a number of children who should have been receiving special education and the rolls of the LCC's special schools rapidly increased from 7,056 to $8,892 .{ }^{12}$ This growth in activity prompted a corresponding expansion of the medical staff. In $1903 \mathrm{Kerr}$ had a staff of three half-time assistants, six oculists, and three nurses. Most of them had taken up their appointments after Kerr's arrival. ${ }^{13}$ By

\footnotetext{
${ }^{5}$ London School Board, Annual Report of the Medical Officer for 1903, p. 1. All LSB and LCC records are deposited in, and quoted by permission of, the Greater London Council Record Office.

- Board of Education, op. cit., note 4 above, p. 22.

'This was one of a number of instances of expenditure of doubtful legal validity which put the Bradford School Board "in bad odour with the Board of Education", according to Sir George Kekewitch. David G. Pritchard, Education and the handicapped, 1760-1960, London, Routledge \& Kegan Paul, 1963, p. 128.

'Including a professorship at King's College Hospital; posts of medical officer to the Bovril and London Milk companies; and appointments as Medical Officer of Health and Public Analyst to Woolwich Borough Council. LSB, Minutes of the Sub-Committee on the Medical Officers Department, 2 May 1901.

${ }^{\circ}$ LSB, Minutes, 1901, 55: 964; 1902, 56: 411.

${ }^{10}$ See James Kerr, 'School Hygiene; its mental, moral and physical aspects', J. Roy. Statist. Soc., 1897, 60: $613-680$.

"See William Turner in Huw W. S. Francis et. al., 'The doctor as educationalist; James Kerr: 1861-1941', Med. Offr, 1970, 123: 303-305.

12 Board of Education, op. cit., note 4 above, p. 23.

${ }^{13}$ LSB, op. cit., note 5 above, p. 1.
} 


\section{A failure "without parallel"}

1908, as a result of a progressive expansion of activity, the staff of the medical department numbered fifty-two, ${ }^{14}$ although many of these were part-time medical staff recruited to help operate Kerr's system of routine medical supervision in schools. Kerr consistently advocated the part-time inspection system, arguing that it was easier to get "first class men", and that it avoided the boredom involved in full-time examination of children.13

Thus by 1907 the LCC was operating its own system of medical supervision of schoolchildren, largely fashioned by Kerr. As the largest education authority in the country, the LCC exerted considerable influence on the educational activities of other education authorities, and its system of school hygiene proved similarly influential. ${ }^{16}$ As head of this service, and by virtue of his own experience, achievements, and personality, Kerr had attained a position of considerable influence. He had given evidence to three important government committees concerned with the welfare of children, was joint secretary to the forthcoming International Congress on School Hygiene, and was much in demand as a lecturer and speaker in the field of educational medicine. He was certainly the best known medical man in the field. Kerr's own view was that "the development of school hygiene in England and its present position in the [London County] Council's schools are in very large measure due to my own personal exertions during the past 16 years." ${ }^{17}$ Thus when the 1907 Act created a need for a Medical Department at the Board of Education, it seemed natural to all, including Kerr himself, that he should be the strongest candidate for the senior appointment.

However, during his years at Bradford and London Kerr had consistently advocated that school hygiene formed a distinctive and independent field of public medicine. School hygiene, he argued, was "recognised in other countries than England as a highly specialised branch of Public Health, which the ordinary sanitarian cannot be expected to follow in its fulness." 18 Therefore, the school doctor was to bear in mind the primarily educational nature of his appointment. "He should regard the teachers as colleagues who can give valuable service, and be prepared to act reasonably at all times, remembering that the school is chiefly for educational purposes, and that extraordinary details as to prophylaxis which might be advisable in individual cases are often out of place in school." 19 A reflection of these views was Kerr's refusal to allow Public Health officials in London to work as part-time school doctors, co-operating with them only when required by law, as with infectious diseases. ${ }^{20}$

\footnotetext{
${ }^{14}$ Board of Education, op. cit., note 4 above, p. 23.

15 Inter-Departmental Committee on Medical Inspection and Feeding of Children Attending Public Elementary Schools, vol. 2, Cd. 2784, oral evidence of Dr. James Kerr, p. 125 ff., BPP 1906, xlvii.

${ }^{16}$ An example of such influence can be found in the list of duties assigned to the Medical Officer to the Kidderminster education authority, quoted approvingly by the Medical Inspection and Feeding Committee (vol. 1, Cd. 2779, p. 4, BPP 1906, xlvii). This is in fact taken verbatim from the LSB Annual Report of the Medical Officer for 1903, p. 25.

${ }^{17}$ Greater London Council Record Office, EO/GEN/5/25, Educational Administration: Special SubCommittee of the General Purposes Committee of the LCC, 1908, App. 6. Evidence of Dr. James Kerr, 19 August 1907.

${ }_{18}$ LCC, Report of the Medical Officer (Education) for 1906-7, p. 3.

19 LSB, Annual Report of the Medical Officer for 1904, p. 42.

${ }^{20}$ Medical Inspection and Feeding Committee, vol. 2, p. 126, question 3784. Ironically George Newman was one of the officials affected. PRO Ed. 24/280, Newman to Morant, 23 September 1907.
} 


\section{J. D. Hirst}

This concept of a school medical service differed from that of Sir Robert Morant, the Permanent Secretary at the Board of Education. Like his friends, Sidney and Beatrice Webb, Morant envisaged school hygiene as a part of an integrated Public Health Service, controlled by a Public Health Ministry. While Beatrice Webb was attempting to persuade the Royal Commission on the Poor Laws to adopt this as a policy, Morant was reluctant to create an independent medical department at the Board of Education. Eventually, he felt forced to do so by the inertia of the Local Government Board, responsible for existing Public Health provision. ${ }^{21}$ Even with an independent department, however, Morant and the Webbs wanted a chief officer who could be guaranteed to develop the service in close conjunction with the local public health departments, ensuring that possible future integration would not be prejudiced. With this in mind, the Webbs introduced George Newman, then the Medical Officer of Health for Finsbury, and author of an important work on infant mortality, whom Beatrice had known since $1900,{ }^{22}$ to Morant at a dinner party at the Webbs' home. ${ }^{23}$ Under pressure from Morant, the Webbs, and their acquaintances, Reginald McKenna, the President of the Board of Education, agreed to appoint Newman, about whom, he told Beatrice Webb, he had "heard nothing but good".24

With Newman's appointment, Kerr's disappointment at not obtaining a position for which he considered himself the best-qualified candidate was given added point by the knowledge that Newman was committed to the administrative development of the School Medical Service along lines which he, Kerr, strongly opposed, linking it closely to the existing Public Health Service. It is also possible that Kerr had even stronger reasons for disappointment. After Newman's appointment had been announced, one of Kerr's subordinates at the LCC, Archibald Hogarth, wrote a vitriolic letter to the British Medical Journal, alleging that Kerr had been promised the appointment at the Board by Augustine Birrell, McKenna's predecessor, the previous year. ${ }^{25}$ This allegation cannot be independently confirmed, but the 1906 Education Bill had been amended to include a requirement for compulsory medical inspection, and by August 1906 this had generated some discussion within the Board of Education as to suitable candidates for the post. ${ }^{26}$ As the Webbs had no influence over Birrell, ${ }^{27}$ some discussion with Kerr may have occurred. Whether or not this influenced Kerr's reactions, he was sufficiently upset by the Board's action to spurn efforts at reconciliation made by Newman, who told Morant: "I wrote to Kerr. He is annoyed apparently - and though I wrote a very friendly and conciliatory letter he replied in a nasty way." 28

In addition to these professional and personal differences a further element in the

${ }^{21}$ British Library of Political and Economic Science, Passfield Papers, diary of Beatrice Webb, vol. 26, p. 57,27 April 1907.

22 Ibid., II 4, n. 263, Newman to Sidney Webb, 1 June 1943.

${ }^{23}$ Herefordshire Record Office, Newman Papers, M4/160, notes on Newman's medical career, and Passfield Papers, II 4, c. 99, Newman to Beatrice Webb, 19 September 1907.

24 Ibid., diary of Beatrice Webb, vol. 26, p. 69, 18 July 1907.

${ }^{25}$ Br. med. J., 1907, ii: 772-773.

26 PRO Ed 24/280, Morant to Alfred Eichholz, 28 August 1907.

${ }^{27}$ Passfield Papers, diary of Beatrice Webb, vol. 25, p. 89, 15 A pril 1906.

28 PRO, Ed 24/280, Newman to Morant, 20 September 1907. 


\section{A failure "without parallel"}

dispute between the Board and the LCC, the importance of which has tended to be overlooked or underestimated in existing studies of this episode ${ }^{29}$ was the political conflict over the financing of the new service. The rapid expansion of educational medicine in London, both under the LSB and the LCC, had taken place under Progressive political control. The 1907 LCC elections, however, had seen a victory for the Moderate (Unionist) group, in a campaign in which the growth of rates and municipal activity had been the major issue. ${ }^{30}$

Much of the political argument of the campaign centred on municipal tramways and improvement policy, but the inclusion of the education rate in the general rate demand of the LCC from 1904 had contributed to the increased political importance of the rates issue. Committed to financial retrenchment, the Moderates had two concerns about the LCC's educational spending. The first was the general expansionary trend, due to increased spending on post-elementary education, teachers' salaries and superannuation, and other developments, in addition to the relatively minor impact of the medical service. The second was the distribution of responsibility for meeting this expenditure. Prior to 1902, the central government Exchequer grants had covered about sixty per cent of the cost of elementary education, with local rates meeting the remaining forty per cent. However, with the passage of the 1902 Education Act (ironically a Unionist measure) local rates began to bear an increasingly larger proportion of the costs, as the table below illustrates:

\section{ELEMENTARY EDUCATION ${ }^{31}$}

\begin{tabular}{llllll}
\multicolumn{3}{l}{ Total } & & & \\
& \multicolumn{2}{l}{ Expenditure } & & & \\
from Grants and & & & \multicolumn{2}{l}{ Proportion borne by } \\
Year & Rates $(\boldsymbol{f})$ & Grants & Rates & Grants & Rates \\
$1904-5$ & $19,326,548$ & $10,669,352$ & $8,657,196$ & 55.2 & 44.8 \\
$1905-6$ & $20,207,017$ & $10,829,396$ & $9,377,621$ & 53.5 & 46.5 \\
$1906-7$ & $20,972,446$ & $11,248,380$ & $9,724,066$ & 53.6 & 46.4 \\
$1907-8$ & $21,303,291$ & $11,023,118$ & $10,280,173$ & 51.7 & 48.3 \\
$1908-9$ & $21,947,360$ & $11,040,100$ & $10,907,260$ & 50.3 & 49.7
\end{tabular}

London, for historical reasons, received a significantly smaller than average proportion of its education costs from Exchequer grants. ${ }^{32}$

Set in this context, the financing of expenditure on the School Medical Service assumed some political importance both nationally and in London. The Moderates had no objection to medical inspection, or indeed to the provision of treatment facilties, but argued that as the School Medical Service was now a national service, it should be funded by the national Exchequer. This position contrasts with the reality that medical inspection attracted no government grant for the period under review.

\footnotetext{
${ }^{29}$ E.g., Gilbert, op. cit., note 2 above, pp. 131-143.

${ }^{30}$ For an account of the 1907 LCC election from a Progressive viewpoint, see A. G. Gardiner, John Benn and the Progressive Movement, London, Ernest Benn, 1925, pp. 329-362.

${ }^{31}$ PRO, Ed 23/223, letter, Board of Education to Treasury, 26 January 1909.

${ }^{32}$ Exchequer grants met $31.0 \%$ of the costs of elementary education in London in $1906-7$, and $31.1 \%$ in 1907-8. GLCRO, EO/GEN/1/19, conference of local education authorities on education grants, 1908.
} 


\section{J. D. Hirst}

All expenditure on medical inspection and treatment had therefore to be met from local rates.

The explanation for this lies in the conviction of the Liberal government that the existing grants system was unjust and inefficient, and urgently needed wholesale reform. The grant system existing in 1907 was a product of years of ad hoc development, with three main grants, all of which could have a different basis for calculation, and numerous subsidiary grants. Calculation and payment of these grants required considerable administrative resources, but despite the complexity of the system, substantial territorial injustice existed, leading to great disparities in the rates levied for educational purposes. ${ }^{33}$ The view of the Liberal government was that to reduce these inequalities and to simplify the system a reduction in the number of separate grants was required. This would require additional resources as a simple redistribution of existing funds would leave too many areas with a net loss of grant. ${ }^{34}$ To commit additional funds before this reorganization, in the form of a specific grant for medical inspection, would be inconsistent with this broader objective.

Thus when the 1907 Bill was debated in Parliament, the government policy was to argue that the additional costs of medical inspection would be met by a subsequent increase in general education grant contingent on a reform of the grant system. ${ }^{35}$ This was proposed in the Elementary Education (England and Wales) Bill 1908, upon the passage of which the amount available for grant was to be increased by $£ 1,400,000$. However, following disagreements over questions of sectarian education, the Bill was withdrawn in December 1908, along with the promised grant increase. ${ }^{36}$

Most unusually, therefore, medical inspection became a duty of local education authorities without any immediate aid from the central government. The failure of the 1908 Bill removed the prospect of an increased grant through a reform in the grant system, and when the Board of Education made subsequent enquiries about giving a specific grant for medical inspection, it was informed that the financial crisis caused by the rejection of Lloyd George's 1909 Finance Bill made such aid impossible. ${ }^{37}$ Medical inspection thus began and continued chargeable only to local rates.

Naturally, this situation attracted considerable criticism from the various local authority associations, whose representatives continually raised the matter in a series of meetings with McKenna, and his successor from April 1908, Walter Runciman. ${ }^{38}$ The Moderate majority on the LCC joined in this collective activity, but also acted independently, lobbying Runciman in June $1908,{ }^{39}$ and sponsoring a conference on the question in December, ${ }^{40}$ which led to a mass lobby of Asquith, Lloyd George, and

${ }^{33}$ See Sidney Webb, Grants in aid: a criticism and a proposal, London, Longmans Green, 1911, pp. 67-79.

${ }^{34}$ PRO, Cab. 37/101/158, The need for an increase of Exchequer grants in aid of elementary education, 12 December 1910.

${ }^{35}$ Hansard, 4th series, 181: 727.

36 P. Rowland, The last Liberal Governments: 1905-1910, London, Barrie \& Rockliff, 1968, pp. $165-166$.

${ }^{37}$ Newcastle University Library, Runciman Papers, Box WR35, Lloyd George to Runciman, 23 February 1910.

${ }^{38}$ See County Councils Association, Official Circular, 1908, p. 24 and The Times, 20 March 1908, p. 16.

39 Ibid., 19 June 1908, p. 14.

${ }^{40}$ GLCRO, op. cit., note 32 above. 


\section{A failure "without parallel"}

Runciman in March 1909.41 Moderate councillors who were also Unionist M.P.s also raised the question individually in the House. ${ }^{42}$ Despite all this activity, grants were not made available until 1912 , and then for medical treatment expenses only. ${ }^{43}$

From the foregoing account, it is clear that the approach taken by the Board of Education to the administration and financing of the National School Medical Service was very different from that desired by the professional staff and governing party of the LCC. It was the expression of these differences in the LCC's administration of its educational medical service after 1907 which eventually forced Newman's condemnation of the LCC in his 1909 Annual Report.

As has been noted, prior to the passage of the 1907 Act, the LCC was already operating a system of "routine" medical inspection of schoolchildren. Under the LCC scheme, "routine" inspection was not a systematic examination of all children in the school, or even of all children in one standard or age group. Instead, head-teachers pre-selected some children for examination, and those remaining were given a brief screening by the visiting school doctor. The method, and the rationale for this approach, were explained by Kerr.

If all the cases known to the teacher are placed on one side, and then all the other children passed before the doctor, he can select any obvious cases for further examination, and at once dispose of the 60 or 70 per cent of practically normal children without further waste of time in weighing, measuring or filling in cards with needless family histories, or records of hair, clothes, boots and shoes, all futile as far as practical purposes of medical treatment are concerned.4

The LCC's "routine" inspection thus reflected one of Kerr's principles, that a primary purpose was to detect, and advance the possible treatment of, defects in schoolchildren. Inspection without treatment was valueless. ${ }^{45}$ As such, Kerr rejected the concept of a general inspection to determine the extent of defects in children. This, he claimed, could be more effectively achieved by inspection of a limited sample of children. ${ }^{46}$ In advocating the statistical method, rather than the prevalent inductive method of accumulating facts, Kerr was in advance of most of his medical contemporaries, as befitted a man awarded the Howard medal of the Royal Statistical Society. ${ }^{47}$

Prior to the 1907 Act, a staff of twenty-four quarter-time doctors, mainly junior hospital staff, were employed to operate the LCC's "routine" examinations. ${ }^{48}$ This staff was insufficient to inspect each school in the LCC area every year, although it was intended that, by visiting each school in turn, all would eventually be visited. With this system in operation, the LCC began to consider the additional demands which the

\footnotetext{
${ }^{41}$ GLCRO, EO/GEN/5/33, 'Increased Exchequer grants for education, minutes of proceedings on 18 March, 1909'.

42 Hansard, House of Commons debates, 5th series, 21, $708 \mathrm{ff}$.

${ }^{43}$ Board of Education, Circular 792, 1912.

44 LCC, Children's Care (Central) Sub-Committee, Agenda, 10 June 1910.

45 LCC, Day Schools Sub-Committee, Agenda, 17 November 1908.

46 Ibid.

${ }^{47}$ See Huw W. S. Francis, 'Education and Health: the English tradition', Publ. Hlth, Lond., 1975 89: 185.

48 Board of Education, op. cit., note 4 above, p. 23.
} 


\section{J. D. Hirst}

1907 Act might make. The Medical Section (a sub-committee) of the Day Schools Sub-Committee noted that: "No definition of what is 'medical inspection' or what 'attending to the health and physical condition of the children' may mean is to be gathered from the Act. These no doubt will be defined later, but as there is no grant, the Board of Education cannot expect much at present." 49

The Medical Section then went on to discuss the question of whether the medical staff should be expanded in anticipation of any new demands the 1907 legislation might make. It noted that the LCC's decision:

depends on whether it is decided to adopt a complete organisation providing for the medical inspection of every child, the recording of all details, and the following up of the child with oversight throughout its school life, or whether the present work is continued and gradually developed pari-passu with other measures. There are at present reasons for rejecting the first plan. The work could not be done without at least 100 quarter-time doctors being added to the staff, and neither teachers, ratepayers nor hospitals are prepared for the consequences.

The Medical Section therefore proposed a modified scheme involving a gradual increase to sixty-four quarter-time doctors over a period of three years. ${ }^{\mathbf{s 0}}$ It was admitted that this would be inadequate to satisfy any stringent interpretation of the 1907 Act.

The Medical Section had met before the Board had given any specific guidance on what it would require under the Act, but by the time the Day Schools Sub-Committee met to discuss the recommendations of the Medical Section, the Board had issued Circular 576 on 22 November 1907. This circular gave preliminary guidance on inspection requirements, suggesting that all children should be examined on three occasions during school life, but also discussed the administration of the new service, stressing the Board's and Newman's view that "the work of medical inspection should be carried out in intimate conjunction with the Public Health Authorities and under the direct supervision of the Medical Officer of Health."'s1

When the Day Schools Sub-Committee met to debate the recommendations of its Medical Section, the agenda papers contained not only Circular 576, but also a commentary by Kerr attacking the circular in trenchant terms. He was particularly critical of the proposal that the School Medical Service should be the responsibility of the Medical Officer of Health, saying that to suggest this was compulsory was "quite ultra vires. There is no compulsion of any county council to appoint a county medical officer of health, and similarly the rest of the paragraph imposes no actual requirement to place medical inspection under the medical officer of health, although at first reading it does so." $\$ 2$ Kerr's conclusion and recommendation was:

The requirements of this memorandum do not necessitate or suggest any need for alteration in our procedure in London. Most of it is mere expression of opinion as to matters with which the London County Council, as a result of their real experience, is more competent than the Board of Education to decide ... the Council are the authority to decide all details of the organisation of the medical service in

49 LCC, Day Schools Sub-Committee, Agenda, 21 January 1908.

so I bid.

${ }^{31}$ Board of Education, Circular 576, 1907, clauses 12 and 5.

52 LCC, Day Schools Sub-Committee, op. cit., note 49 above. 


\section{A failure "without parallel"}

the schools, and the Board of Education's opinions need not further be considered as in any way constituting a mandate for change. ${ }^{33}$

The Sub-Committee resolved to expand the number of part-time doctors on the lines proposed by its Medical Section, despite the acknowledged inadequacy of such action to meet the full requirements of Circular 576.

These initial responses from the LCC indicate the twin themes of the Council's response: the political concern about the future cost of medical inspection, and Kerr's dispute over the professional control of the service, and the objects and method of medical inspection. Although the LCC decided to proceed along the lines suggested by the Day Schools Sub-Committee, the Council's deviation from the expressed wishes of the Board of Education was further accentuated when Cyril Jackson, the Moderate Chairman of the Education Committee, vetoed the appointment of additional school doctors in order to demonstrate to the Board the LCC's desire for financial assistance. This delayed implementation of improvements to Kerr's system of routine inspection by at least six months. ${ }^{34}$

Although the LCC's decision meant that Kerr could justifiably, if rather indiscreetly, claim publicly that the Council was prepared to ignore the Board, ${ }^{55}$ the LCC continued to discuss with the Board how far Kerr's routine system could be held to meet with the Board's requirements. With the publication of the 1908 Education Code in July 1908, satisfactory medical inspection became a pre-condition for the payment of Education Grant, ${ }^{36}$ a provision which considerably strengthened the powers of the Board. Following this, the LCC was warned that "The Board do not consider that it was the intention of Parliament that medical inspection should be confined to children selected for obvious defects." 37 This meant, the Council was told by Blair, the Education Officer, that the Board was unlikely to accept that inspection on Kerr's system satisfied the provisions of the Code..$^{58}$ The Board's own recommendations for medical inspection, issued as Circular 582 on 23 January 1908, called for a systematic medical inspection of all "entrants" and "leavers". 59

Despite the Board's advice, Kerr continued to insist that the LCC possessed some autonomy in the interpretation of the Board's requirements, suggesting, "Obviously, so long as the children entering school after 1 August, 1908, and children leaving school before $1 \mathrm{July,}$ 1909, are examined, the details of all the examinations need not be comprehensive." ${ }^{60}$ Kerr proposed therefore as an experiment, that each part-time school doctor would examine the children in one school under the Board's schedule, and in one further school under a simpler schedule devised by Kerr, "which, I think,

\footnotetext{
53 Ibid.

s4 Ibid., 13 October 1908.

ss The Times, 19 June 1908, p. 14.

36 Board of Education, Code of Regulations ... for 1908, Cd. 4158, p. i (preface). BPP1908, Ixxxii. The Code amended Circular 576, to provide that initially the Board would require inspection only of "entrants" and "leavers", with the inspection of a third group being postponed.

57 LCC, Day Schools Sub-Committee, Agenda, 13 October 1908.

38 Ibid.

\$9 Board of Education, Circular 582, 1908.

${ }^{60}$ LCC, Day Schools Sub-Committee, op. cit., note 45 above.
} 


\section{J. D. Hirst}

will take about a quarter of the time and probably attain nearly equal results. For the rest of the schools, we must carry out the present method, somewhat slightly extended, of examining all the children selected by the teachers according to instructions, and also sampling classes." 61 With the number of part-time school doctors then on the staff, this proposal meant that only forty of the 900 schools in the LCC area would be subject to inspection according to requirements of the Board. Despite this obvious shortcoming, the LCC submitted a proposal on similar lines to that of Kerr for the approval of the Board of Education.

In dealing with the LCC's application the Board was faced with a number of difficulties. The LCC was clearly unable to fulfil the Board's requirements, especially as the proposals were not submitted until some time into the school year, but the Board feared that too hasty an enforcement of the requirements of the Code would heighten the conflict with the local authorities over the cost of medical inspection. Additionally, the Board's Medical Department was under-staffed, and would find it difficult to carry out the inspections required to enforce the Code. The Board therefore replied that, with great hesitation, it had agreed to sanction the LCC's scheme for the 1908-9 school year, although it doubted whether the LCC would have sufficient staff to implement it satisfactorily, and warning that the LCC's plans for future years would be subject to a more searching scrutiny. "It must not be assumed that, in considering the adequacy of such proposals, the Board will adopt the same standard of efficiency as they feel justified in applying to a scheme of an initiatory character."'62

The Board believed the best approach was to allow the LCC more time to bring its system of medical inspection into line with the Board's requirements. This sanction allowed the LCC to continue with the use of Kerr's routine inspection, coupled with the introduction of systematic inspection according to the schedules of the Board, and of Kerr, in a small number of its schools.

However, from the middle of 1909 onwards, the LCC's medical inspection programme was transformed by the demands made upon it by the Council's arrangements for the treatment of defects discovered. From the beginning of its vision testing programme in 1899 , the London education authority had been concerned to ensure that inspection resulted in treatment where this was needed. Lacking legal powers to provide treatment, both the LSB and the LCC had resorted to referring children to the out-patient departments of the various voluntary hospitals in London, a practice which resulted in a number of protests from the voluntary hospitals. ${ }^{63}$ When the 1907 Act conferred on the LCC powers to spend money on treatment facilities, the Council decided, with protests from the voluntary hospitals continuing, to examine how best these powers could be used. A Sub-Committee, composed of members of the LCC and representatives of the medical profession and of charitable organizations, first met in February 1908, and over the following nine months heard much evidence on the

61 Ibid.

62 LCC, Education Committee, Minutes, 24 March 1909.

${ }^{63}$ See J. D. Hirst, 'Vision testing in London; a rehearsal for the School Medical Service', J. Educ. Admin and Hist., [forthcoming]. 


\section{A failure "without parallel"}

medical needs of the capital's schoolchildren, and the ways in which they could be met.

Kerr and most other professional witnesses giving evidence to the committee urged the establishment of a number of school clinics operated by the Education Committee. ${ }^{64}$ However, the Moderate members of the Sub-Committee, for financial and ideological reasons, preferred the alternative option: to continue to use the existing voluntary institutions, paying them to act as agents for the LCC. When the Moderate chairman of the Sub-Committee, Henry Gooch, moved that it be recommended that agreements be made with the voluntary hospitals to treat the schoolchildren, his motion was defeated by an alliance of Progressive councillors and most of the co-opted medical representatives on the Sub-Committee, led by Sir Victor Horsley, a prominent member of the British Medical Association delegated to act as its representative. This alliance then passed a motion in favour of a school clinic system. ${ }^{65}$ However, when the full Education Committee considered the recommendation, the Moderate majority adopted a resolution advocating the use of the voluntary institutions. ${ }^{66}$

This decision angered the BMA, caused considerable controversy in the medical profession, and deeply disappointed Kerr, who was not, however, responsible for its implementation. On the somewhat dubious ground that obtaining medical treatment for schoolchildren was a purely administrative function, the operation of the treatment scheme was in the hands of Blair, the Education Officer to the Council, ${ }^{67}$ meaning that "London had the unique and Gilbertian situation of its medical officer directing medical inspection in schools while the education officer directed medical treatment in hospitals." 68

It was thus Blair who conducted the negotiations with the voluntary hospitals. These met with some difficulties. The hospitals, mindful of their experiences with vision test referrals, wanted limits placed on the number of children to be treated, and full payment of their additional costs. They were also concerned that payments from the LCC should not entail Council representation on their governing bodies, or interference from the LCC's medical staff. ${ }^{69}$ These difficulties were overcome, and in succeeding months the LCC concluded agreements with a number of hospitals. By December, the LCC approached the Board asking for sanction (as was required by the 1907 Act) to implement a treatment scheme involving payment to, initially, eight voluntary hospitals. Although the arrangements were the subject of considerable political and professional controversy, Newman recommended approval. He envisaged that the arrangements would encounter considerable administrative and

\footnotetext{
64 LCC, Education Committee, Agenda, 9 December 1908, pp. 75-116, Report of the Special SubCommittee on Medical Treatment.

${ }^{65}$ LCC, Special Sub-Committee on Medical Treatment, Minutes, 20 November 1908. Five of the six medical men on the Sub-Committee voted for the establishment of clinics.

${ }^{66}$ LCC, Education Committee, Minutes, 16 December 1908.

${ }^{67}$ LCC, Children's Care (Central) Sub-Committee, Agenda, 6 February 1911.

68 Sir Gwilym Gibbon and R. W. Bell, History of the London County Council: 1889-1939, London, MacMillan, 1939, p. 301.

${ }^{69}$ LCC, Day Schools Sub-Committee, Agenda, 16 February 1909.
} 


\section{J. D. Hirst}

practical difficulties, but argued that only experience of the scheme would prove this point. The Board therefore gave approval for a period of twelve months. ${ }^{70}$

The introduction of the hospital treatment scheme caused considerable disruption to the LCC's inspection scheme. Under the financial arrangements made with the hospitals, the LCC guaranteed to pay the hospitals $£ 50$ per annum for each half-day that an assistant hospital doctor was available to treat children referred by the Council, irrespective of whether any children attended for treatment. A capitation fee of two shillings per child attending would also be paid. ${ }^{11} \mathrm{With}$ a relatively high proportion of fixed costs, the LCC had to ensure that sufficient numbers of children attended the treatment sessions in order to bring treatment costs to the desired figure of under five shillings (25p.) per case.

Apart from the drawbacks of using out-patient departments, and the labyrinthine bureaucracy by which the scheme was administered, with ten different communications between six separate officials of the LCC Education Department and the hospital required for each case, ${ }^{72}$ there were two main problems in achieving this target. First, under a private member's Bill instigated by Moderate members of the LCC, councils had to charge for treatment given under the School Medical Service. ${ }^{73}$ As parents were often still able to obtain treatment free of charge for their children in hospitals outside the LCC scheme, and were infuriated by the anomaly created whereby they, and any children below school age, could still obtain free treatment at hospitals in the LCC scheme, many refused to send their children for treatment under the School Medical Service. ${ }^{74}$ Second, as Kerr had pointed out to the Sub-Committee on Medical Treatment, "practically the whole of the chief hospitals were in the central districts of London, whilst the child population was frequently at considerable distances from any hospital." 75 This meant that for practical purposes it was useless to attempt to send children from many areas of London to hospitals where arrangements for treatment had been made. So in order to supply a sufficient number of cases for treatment, the medical inspection staff had to concentrate their attentions on schools in the immediate vicinity of the hospitals.

The result of the needs of the treatment system was revealed to the LCC in May 1910, when Kerr submitted a report on the progress of medical inspection to the end of 1909. The experimental use of the two inspection schedules was proceeding normally, with Kerr's simplified schedule taking less time to complete, as shown in the tables reproduced below.

\section{CHILDREN INSPECTED TO 31 DECEMBER $1909^{76}$}

\begin{tabular}{ccccccccc}
$\begin{array}{c}\text { Number of } \\
\text { schools }\end{array}$ & $\begin{array}{c}\text { Schedule } \\
\text { used }\end{array}$ & $\begin{array}{c}\text { Number } \\
\text { on roll }\end{array}$ & $\begin{array}{c}\text { Number } \\
\text { entering }\end{array}$ & $\begin{array}{c}\text { Number } \\
\text { leaving }\end{array}$ & $\begin{array}{c}\text { Presented } \\
\text { by teacher }\end{array}$ & $\begin{array}{c}\text { \% Parents \% Treatment } \\
\text { attending }\end{array}$ & $\begin{array}{c}\text { Time } \\
\text { advised }\end{array}$ & per child \\
\hline 39 & Bd. of Ed. & 25632 & 2539 & 1042 & 971 & 71.8 & 30.5 & $8^{\prime} 58^{\prime \prime}$ \\
31 & Kerr & 33363 & 4565 & 960 & 349 & 68.5 & 31.4 & $6^{\prime} 43^{\prime \prime}$ \\
\hline
\end{tabular}

70 PRO, Ed. 125/9, Precedent files: LCC, 1 December 1909.

$"$ LCC, Educational Committee, Minutes, 3 November 1909.

72 LCC, Children's Care (Central) Sub-Committee, Agenda, 27 January 1911. 


\section{A failure "without parallel"}

The third element, the "routine" inspection of entrants and leavers in the other schools in the LCC area, had been abandoned completely. Instead, the school doctors had concentrated on a number of schools near the hospitals in the treatment scheme. In these,

The mode of procedure is much the same as that adopted in the detailed examination, except that every child in the school is examined instead of those entering or leaving as prescribed by the Board of Education Code and Memoranda. The work has been carried out on the "simpler plan". Up to 28 December, 28 schools have been examined, with the following results: ${ }^{77}$

\begin{tabular}{cccccc}
$\begin{array}{c}\text { Number of } \\
\text { schools }\end{array}$ & $\begin{array}{c}\text { Number } \\
\text { on rolls }\end{array}$ & $\begin{array}{c}\text { Number } \\
\text { examined }\end{array}$ & $\begin{array}{c}\text { \% Parents } \\
\text { attending }\end{array}$ & $\begin{array}{c}\text { Treatment } \\
\text { advised }\end{array}$ & $\begin{array}{c}\text { Time per } \\
\text { child }\end{array}$ \\
\hline 28 & 22883 & 22231 & 59.1 & 35.7 & $4^{\prime} 52^{\prime \prime}$ \\
\hline
\end{tabular}

Kerr was later to argue that he had been instructed to implement this rearrangement of the school doctors' duties, presumably by Blair. ${ }^{78}$ However, the close link thus created between inspection and treatment was entirely consistent with Kerr's own opinions on the subject, and in another discussion, he was prepared to question "whether it is not wiser to examine children in areas where there is a possibility of treatment rather than a smaller number from each school throughout the metropolis. Our action [in concentrating the inspectors in a small number of schools] has been purely to avoid wasteful work." 99 This suggests that Kerr did not need much persuasion to change to the new system. The change meant, however, that of the 148,000 London schoolchildren who, by the LCC's own estimates, would be either "entrants" or "leavers" during the 1909-10 school year, ${ }^{80}$ by the end of 1909 the Council had managed to inspect only 3,581 or 2.4 per cent of the total, in accordance with the inspection schedule of the Board of Education. Even if those inspected according to Kerr's schedule are included, those satisfactorily inspected amount to only 6.2 per cent of the total to be inspected, to which must be added those "entrants" and "leavers" in the schools where all children were inspected. Thus under these arrangements most of the schools in the LCC area were not visited by the school doctors. These figures illustrate the extent of the failure, according to the standards of the Board of Education, of the LCC's medical inspection programme in 1909-1910 and explain why Newman felt obliged to make such a forceful criticism in his Annual Report for 1909. It should be noted, however, that even if the medical inspection staff had not been diverted from their normal duties, their numbers were insufficient to inspect the required number of "entrants" and "leavers". In the nine months covered

\footnotetext{
13.

${ }^{73}$ Local Education Authorities (Medical Treatment) Act, 1909. Public General Acts, 9 Edw. VII, cap.

"7 See letters in The School Child (a journal for members of school care committees in London), for February 1910.

${ }^{75}$ LCC, Education Committee, Agenda, 9 December 1908, p. 116.

${ }^{76}$ LCC, Children's Care (Central) Sub-Committee, Agenda, 5 May 1910.

7 Ibid.

78 Ibid, 24 November 1910.

79 Ibid, 16 June 1910.

80 Ibid.
} 
by Kerr's report, the quarter-time inspectors, originally forty, then fifty-six strong, had inspected only 32,657 children. Even when the inspecting staff reached its envisaged strength of seventy-two in September 1910, numbers would be insufficient to meet the Board's regulations.

The failings of the LCC's inspection scheme were now attracting considerable public criticism. The Progressive minority attacked the "profoundly unsatisfactory" provision at every opportunity, ${ }^{81}$ voluntary workers wrote letters of protest to the The Times, ${ }^{82}$ and Sir Victor Horsley, in a number of public speeches, added the weight of the medical establishment to the protests. ${ }^{83}$ In April 1910, Newman had been assured by Runciman that he was determined to fight the LCC until it carried out the 1907 Act, ${ }^{84}$ and this political backing, coupled with an increase in the staff of the Medical Department, meant that the Board could begin to press the LCC more strongly. This resulted in a letter from the Board in May 1910, warning the LCC that its staff of inspectors, even with the proposed increase to seventy-two in September 1910, was considered inadequate for the Council to meet the Board's requirements. ${ }^{85}$

The LCC's response was initially considered by a section of the Children's Care (Central) Sub-Committee, advised by Kerr. This decided to recommend a further increase of twenty-eight in the number of part-time inspectors from January 1911, making a total of $100 .{ }^{86}$ Although it is impossible to be definite, due to uncertainty about the proportion of time the inspectors would be spending on duties other than the medical inspection of schoolchildren, such a staff, or its full-time equivalent, would have been proportionately comparable to those maintained by other large urban authorities for the inspection of "entrants" and "leavers". ${ }^{87}$ Such simple resolutions of the difficulty, however, were not for Kerr. He argued, not without justification, that "entrants" were too young, and "leavers" had too short a period left at school, for inspection of those groups to be followed by effective remedial treatment. The increase in staff, coupled with the use of his own simpler schedule of inspection, would therefore allow the inspection of a third group of eight- to nine-year-old children, and additional urgent cases submitted by teachers. Although the addition of the third group would raise the number to be examined to approximately 220,000 children each year, Kerr argued, on the basis of figures he submitted, that the increased staff could cope with these demands. ${ }^{88}$

Consideration of Kerr's new proposals proceeded in tandem with discussion of a further letter from the Board, sent on 7 October 1910. This again stressed the Board's view that the inspection staff was inadequate, and developed a further area of criticism by suggesting that the supervision and co-ordination of the part-time inspectors was

\footnotetext{
${ }^{81}$ Lancet, 1910, i: 1634.

82 The Times, 28 October 1910, p. 6.

${ }^{83}$ Ibid., 12 December 1910, p. 13.

${ }^{84}$ Herefordshire Record Office, Newman Papers, M4/159, notes by Sir George Newman for his proposed autobiography.

${ }^{85}$ LCC, Children's Care (Central) Sub-Committee, Agenda, 16 June 1910.

${ }^{86}$ LCC, Children's Care (Central) Sub-Committee, Minutes of sections, 24 June 1910.

${ }^{87}$ GLCRO, PH/SHS/1/14, Medical Inspection: general inquiries file.

88 LCC, Children's Care (Central) Sub-Committee, Agenda, 30 June 1910.
} 


\section{A failure "without parallel"}

less than adequate. ${ }^{89}$ From published accounts, it is clear that the inspecting staff had considerable independence of operation, including absolute flexibility over when to perform their three half-days of duty. ${ }^{90}$ When the LCC, as a result of the Board's pressure, decided to agree fixed days of attendance with the school doctors, a number found considerable difficulty in doing so. ${ }^{91}$

Kerr dismissed the Board's criticisms, saying that they related only to the "temporary arrangements" for inspection for treatment. ${ }^{92}$ When discussion turned to the proposed increase in inspection staff, Kerr's calculations were attacked in detail by one member of the LCC, who claimed the staff were expected to inspect far more children each year than the Board of Education thought possible. However, the Chairman of the Education Committee, Cyril Jackson, "asked the Council to rely on the opinion of Dr. Kerr, who was the pioneer of medical inspection in this country, that the proposed staff was adequate." 93 In approving the scheme, the committee was approving Kerr's executive action, for he had ordered inspection of the three groups to begin on 1 October $1910 . .^{94}$

Subsequent reports to the Education Committee appeared to justify Kerr's optimism. In February 1911, the Committee was told that 82,847 children had been inspected between August and December 1910, of whom 46,214 were "entrants" or "leavers". In order to inspect all the 149,600 such cases by the end of July 1911, some 3400 entrants and leavers needed to be dealt with each week, or 61,200 by the end of December. There was thus a deficit of 14,986 cases but, the Committee was told, prior to 20 October 1910, only part of the inspecting staff was engaged in the inspection of entrants and leavers. From that date, the seventy-two inspectors had dealt with 3800 such cases a week, while the full staff of 100 were expected to deal with 5280 weekly cases. Thus it was anticipated that the deficit would be cleared by Easter, and the full programme of inspection of all entrants, leavers, and eight- to nine-year-olds completed by July. ${ }^{95}$

Although an apparent vindication of Kerr, the transformation implied by these statistics, from the LCC being an authority in total breach of its obligations under the 1907 Act to one performing over and above the basic requirements, was more apparent than real. In his anxiety to include inspection of the eight- to nine-year-olds, Kerr was prepared to compromise over the inspection of the statutory groups, and persuaded the Children's Care (Central) Sub-Committee to agree "That as from 1st January 1911 , a card be prepared by the head teacher, in respect of every 'entrant', ... that this card be initialled by the school doctor, and that the school doctor shall examine the children individually only when he considers a detailed examination necessary." 96

\footnotetext{
${ }^{89}$ Ibid., 20 October 1910.

${ }^{90}$ See "A late School Doctor, A few details as to the work required of an Assistant School Doctor in London', Sch. Hyg., 1910, 1: 391-395.

${ }^{1}$ LCC, Children's Care (Central) Sub-Committee, Agenda, 27 October 1910.

92 Ibid., 20 October 1910.

${ }_{93}$ Lancet, 1910, ii: 1364-1365.

94 LCC, Children's Care (Central) Sub-Committee, Agenda, 20 October 1910.

95 Lancet, 1911, i: 394.

${ }^{9}$ LCC, Children's Care (Central) Sub-Committee, Minutes of sections, 25 October 1910.
} 


\section{J. D. Hirst}

According to investigations by the BMA, this regulation meant that only about twenty-five per cent of the entrants were actually given a detailed medical examination, using Kerr's abbreviated schedule. These were the entrants picked out from amongst those paraded in front of the visiting doctor ${ }^{97}$ However, although the school doctors returned statistics of entrants according to whether they had been "seen", or whether they had actually been medically examined, the LCC amalgamated these two lists for publication, implying that all such children had been inspected individually. ${ }^{98}$ In reality, therefore, the LCC was not complying with the Board's demands for individual inspection of all entrants, and was in any case using Kerr's simplified schedule for all individual inspections, making the Board's task of compiling national statistics almost impossible.

Thus between 1907 and 1912, the scheme for the medical inspection of children in London schools passed through three distinct phases, similar only in their failure to comply with the requirements of the Board of Education. In this light, it can be appreciated why Newman felt compelled to publish such strong criticisms of the LCC. However, despite the continuing failure of the inspection scheme to meet the Board of Education's requirements, the difficulties of the LCC's treatment scheme provided the final stimulus for the re-organization of the LCC's medical provision for schoolchildren. Although the Board had given approval for the hospital treatment scheme to operate for a trial period of twelve months, with further approval conditional on a satisfactory report on the operation of the system, the LCC neglected to apply for approval for an extension of the scheme until 20 December 1910, eleven days before sanction for the scheme expired.99 In practice, the cumbersome bureaucracy, requirement for payment, and problems of out-patient care had combined to create such severe difficulties for the hospital treatment scheme that Moderate support for the system had become much more muted. ${ }^{100}$ Kerr had supplied Blair with the names of 56,054 children found on inspection to require treatment, but it had proved impossible from this list to find the 21,590 cases the LCC's treatment scheme provided for. ${ }^{101}$

Replying to the LCC's request for further sanction for the treatment scheme, the Board revealed that they were aware of these defects as a result of investigations which Newman and his staff had carried out. The Board gave sanction for the treatment scheme to continue for six months, but only on condition that the Council reformed its administrative arrangements, for, "unless the Council's administration is to be gravely discredited it is essential that the machinery for the selection, admission, registration and following up of children coming within the scope of the treatment scheme should be reformed without any delay."

The separate administration of inspection and treatment was singled out for particular criticism. ${ }^{102}$ Although the LCC was now disposed to accept unification of

\footnotetext{
97 PRO, Ed 24/282, Minutes of meeting with BMA deputation, 27 June 1911.

98 Ibid.

99 LCC, Children's Care (Central) Sub-Committee, op. cit., note 72 above.

100 Lancet, 1910, ii: 1437.

101 LCC, Children's Care (Central) Sub-Committee, Agenda, 24 November 1910.

102 Ibid, 27 January 1911.
} 


\section{A failure "without parallel"}

inspection and treatment, the various officers concerned fought vigorously to gain a personal advantage from the proposed reorganization. Thus the Children's Care (Central) Sub-Committee was faced with three memoranda on reorganization; one from Robert Blair, suggesting that he, as Education Officer, should take responsibility for the two services; one from Sir Shirley Murphy, the Medical Officer of Health, suggesting that the Public Health department should be responsible; and one from Kerr, arguing that he should be given Chief Officer status, and overall responsibility for all school health services in London. ${ }^{103}$ Blair gained the support of the SubCommittee, and of the full Education Committee, but on 25 July 1911 a full meeting of the LCC supported the view of the Clerk to the Council, Sir Laurence Gomme, that the work should be under the supervision of the Medical Officer of Health. ${ }^{104}$ The transfer was to take place from January 1912, when Murphy retired and was succeeded by Dr. Hamer. An inevitable consequence of this is recorded later, when Kerr, never a satisfactory subordinate, was relieved of his executive responsibilities, and given the nominal title of "Medical Research Officer". ${ }^{105}$ As such, he took little part in the rapid reorganization of medical inspection which took place under Hamer. By August 1912, the part-time inspectors had been replaced by a staff of thirty-four full-time officers, using the Board of Education's inspection schedule, and the Board was sufficiently satisfied to award the LCC almost $£ 13,000$ of the newly introduced central government grant. ${ }^{106}$ Although the Board continued to suggest improvements to the LCC's new system, there were no further major conflicts of opinion.

With the LCC's adoption of systems of administration and medical inspection broadly conforming to the requirements of the Board of Education, what conclusions may be drawn from an analysis of the previous five years of dispute? In Professor Gilbert's discussion of the controversy, James Kerr is portrayed as refusing to cooperate with the Board, and obstructing attempts to establish school clinics, as a result of his annoyance at Newman's appointment to the Board of Education. Gilbert suggests that it was Kerr's preference for hospital treatment rather than a school clinic system, which eventually aroused the opposition of the BMA and brought about Kerr's defeat. ${ }^{107}$

As the evidence presented here shows, this interpretation of events is incorrect. In 1908, Kerr's evidence to the Special Sub-Committee on Medical Treatment strongly advocated consideration of school clinics as the most effective means of treatment. ${ }^{108}$ That continued use was made of the out-patients' departments of the voluntary hospitals was due to a political decision by the Moderate group, whose preference was partly influenced by ideological considerations (they had been elected on a platform which opposed the growth of municipal activities), and partly due to their financial concern at the potential cost of school clinics, in the absence of any Exchequer grant. In even proceeding with the optional provision of treatment, the Moderates were

\footnotetext{
${ }^{103}$ Ibid, 6 February 1911.

104 LCC, Council Minutes, 25 July 1911.

10 Ibid., 14 May 1912.

${ }^{106}$ LCC, Annual Report for 1912, vol. 3, Public Health, p. 121.

107 Gilbert, op. cit., note 2 above, p. 140.

${ }^{108}$ LCC, Education Committee, Agenda, 9 December 1908.
} 


\section{J. D. Hirst}

adopting a more enlightened attitude than many other local education authorities, which, in the absence of grant-aid, did no more than the minimum legally required, and sometimes not even that. ${ }^{109}$ Not only was Kerr an advocate of school clinics, but he could not be held directly responsible for the chaos which followed the adoption of the hospital treatment system, for, as part of the aggrandizement of Robert Blair's administrative empire, responsibility for treatment rested with the Council's Education Officer.

Yet, indirectly, the adoption of the hospital treatment system contributed to Kerr's demise, in that he was then required to acquiesce in an inspection scheme which sought to meet the needs of the treatment scheme, but, in the process, abandoned the tenuous links with the Board of Education's preferred system of inspection which Kerr's previous "routine" inspection had possessed. Despite his subsequent denial, it is unlikely that Kerr had to be coerced into this change, for the close link between inspection and treatment conformed to one of the main tenets of his system of school hygiene. He also had other reasons for opposing the Board's scheme of examination in detail of all children in the prescribed age groups, being contemptuous of the mechanical collection of statistics which he believed this implied. In this, Kerr reveals the advanced nature of his views. Few other medical officers of the day were able to use statistical correlation coefficients in their annual reports, ${ }^{110}$ while more recent discussion of the role of the School Health Service has tended to place greater emphasis on selective methods of inspection similar to those advocated by Kerr. ${ }^{111}$ But, in emphasizing that the Board's charges of failure were defined in terms of what Kerr considered a limited conception of the objectives of medical inspection, consideration must be given to the overall context within which the Board was working.

Even if all Kerr's part-time inspectors had been deployed exclusively on the medical inspection required by the Board, for most of the period under review their numbers would have been insufficient to make the number of inspections required. While this shortfall was in part due to Kerr's insistence that his alternative forms of inspection were quicker, simpler, and therefore cheaper, the major factor was the Moderate majority's decision not to provide a full complement of inspection staff until some promise of a central government grant was forthcoming. This attitude was mirrored in many of the remaining 327 education authorities in England and Wales, some of which did not share the Moderates' basic belief in the value of medical inspection. The months following the issue of Circular 576 saw many examples of authorities attempting to provide the basic minimum of medical inspection, ${ }^{112}$ or even, briefly, refusing to introduce it. ${ }^{113}$

In this situation Newman, appropriately for a protégé of the Webbs, adopted a pragmatic strategy of "gradual and slow growth", aiming "not at the best, but at the best that is practicable". ${ }^{114}$ In the absence of a grant-in-aid, securing a minimum

\footnotetext{
109 PRO, Ed 125/11, Precedent covers: Salford, November 1911.

110 LCC, op. cit., note 18 above.

${ }^{111}$ Francis, op. cit., note 47 above, p. 185 ff.

112 Lancet, 1908, ii: 1155.

${ }^{113}$ County Councils Association, Official Circular, 1908, p. 50.

114 Publ. Hlth, Lond., 1908-9, 22: 161.
} 


\section{A failure "without parallel"}

uniform standard of inspection was, initially, the maximum feasible objective. A general progression beyond this minimum required a greater incentive to the local authorities, the effectiveness of which is shown by the rapid expansion of provisions for treatment after these became eligible for grant in 1912.115 Before the introduction of grants, which were later extended to inspection also, the only way Newman could influence some of the more recalcitrant authorities was to remind them of the Code's requirement that medical inspection should conform to the specifications of the Board.

Given the difficulties encountered by the Board at the inception of the School Medical Service, and particularly the absence of grant-aid to the authorities, it is interesting to speculate on the outcome had Kerr in fact been appointed Chief Medical Officer. Certainly, his views on the role of medical inspection and the objects of educational medicine can be said to have been more advanced than those of Newman. In London, however, Kerr had the advantage of working for an authority which was, relatively speaking, progressive, even when not controlled by the Progressives. Whether a man who was "ready to ride rough-shod over any traditional custom", and who could be "brusque and tactless", 116 had the appropriate qualities to persuade and cajole authorities which did not share his enthusiasm for school hygiene to implement medical inspection, is debatable. Certainly, it was questioned by one contemporary, who in response to the campaign in the British Medical Journal against Newman's appointment wrote:

It is not difficult to realise that if Dr. Kerr had been appointed to the Education Department, and if he shares the views of his friends, twelve months would not have passed without the Education Department being embroiled with half the local authorities in the country. It is not impossible that the Education Department had this prospect in view when they did not appoint Dr. Kerr. ${ }^{117}$

\section{SUMMARY.}

The introduction of the medical inspection of schoolchildren in 1907 was a step which attracted a wide measure of support, but the administration of the new service at local authority level was not without its problems. In particular, the work of the London County Council, the largest education authority in the country, was severely criticized in the Annual Report for 1909 of the Chief Medical Officer to the Board of Education, George Newman.

The Council's difficulties derived from two main sources. First, London had a comparatively long tradition of providing some medical supervision in its schools, during the course of which its medical officer from 1902 onwards, Dr. James Kerr, had developed a distinctive concept of school hygiene at variance, both in administration and operation, from that being promoted by the Board of Education. Second, the absence of a central government grant-in-aid for the cost of medical inspection angered the Moderate (Unionist) administration of the Council, who were committed to a policy of financial retrenchment.

\footnotetext{
11 Board of Education, Annual Report of the C.M.O. for 1914, Cd. 8055, p. 91. BPP 1914-16, xviii.

116 Burt and Fairfield, in Francis et. al., op. cit., note 11 above, pp. 303-305.

117 Br. med. J., 1907, ii: 941.
} 


\section{J. D. Hirst}

Influenced by a combination of these factors, the Council's system of medical inspection passed through three distinct phases between 1907 and 1912, alike only in their failure to meet the requirements of the Board. Not until an administrative reorganization had taken place did the Council's system of inspection become acceptable to the Board of Education.

The evidence presented suggests that the history of the dispute given in Professor Bentley B. Gilbert's The evolution of National Insurance in Great Britain (pp. $131-143)^{118}$ requires amendment, and raises questions about how the development of the service would have progressed if, as might at one time have been possible, $\mathrm{Dr}$. Kerr had been appointed to the post of Chief Medical Officer at the Board.

${ }^{118}$ Gilbert, op. cit., note 2 above. 